\title{
Financial compensation and talent retention in COVID-19 era: The mediating role of career planning
}

\author{
Mevan Salih Rasheed ${ }^{a}$, James Yohana Odeesh ${ }^{a *}$ and Toreen Ahmad Ibrahim ${ }^{b}$
}

${ }^{a}$ Business Management Department, Technical College of Administration, Duhok Polytechnic University, Kurdistan Region, Iraq ${ }^{b}$ Business management Department, Duhok Administration Technical Institute, Duhok Polytechnic University, Kurdistan Region, Iraq

\begin{tabular}{l}
\hline C H R O N I C L E \\
\hline Article history: \\
Received: June 12, 2021 \\
Received in revised format: \\
July 22021 \\
Accepted: August 10, 2021 \\
Available online: \\
August 11, 2021 \\
\hline Keywords: \\
Financial Compensation (FC) \\
Career Planning (CR) \\
Talent \\
Talent Retention (TR) \\
Duhok Kidney \& Diseases Trans- \\
plantation Center (DKDTC) \\
COVID-19
\end{tabular}

\section{A B S T R A C T}

This research seeks to contribute to the retention Duhok kidney \& diseases transplantation center (DKDTC), and health organizations their talent in COVID-19 era. To achieve this objective, we use (IBM SPSS Amoss V.22) to analyze the mediating role of career planning (CP) in the relationship of financial compensation (FC) with talent retention (TR) in DKDTC. The data collected was analyzed through 63 questionnaires, which was distributed to the talents working in DKDTC from May 2020 to March 2021. The researchers reached several conclusions, the most important of which are that $\mathrm{CP}$ has a partial mediating role in the relationship between FC and TR. Therefore, this research recommends enhancing the ability of DKDTC and health organizations to TR in a COVID-19 era and they must be relying on FC, and a program that includes clear steps in $\mathrm{CP}$.

\section{Introduction}

Talents are priceless assets in organizations, since they cannot perform their operations without possessing talents that have the potential and abilities that are the main success factors of an organization's growth, overcoming barriers, challenging, and changing what is commonplace. For organizations to achieve their strategic objectives (Bani-Hani, 2021), attention must be given to talent retention (TR). Talent is defined as human resources that have the capacity to achieve performance that exceeds the accepted rate and is commensurate with certain expectations (Moczydlowska, 2012). To (TR), financial compensation (FC) is one of the most important factors that it takes to stay and work for long periods with organizations. This is confirmed by Ivancevich (2010) that one of the objectives of FC is to maintain the talents existing in the organization through the adoption of the principle of justice and equality in it. There are many factors that help the organization to TR, including the existence of CP that provides and serves the career growth of talents with great professional experience through their transition between works (Oladapo, 2014). COVID-19 impacts in all areas and change work experience for most human resources including talents (Collings, et al., 2021; Collings, et al., 2021), therefore, the problem of the study is framed in the identification of the relationship between FC and TR and what is the role of CP in promoting this relationship within the health sector at the Duhok kidney and diseases transplantation center (DKDTC).

\section{Literature review}

\subsection{Financial Compensation (FC)}

Financial Compensation (FC) is very important motivated feature Approve by the human resources management for the performance of talents as well as for the organization, is described as the output that talent receives for its performance and

\footnotetext{
* Corresponding author.

E-mail address: james.odeesh@dpu.edu.krd (J. Y. Odeesh)

(C) 2022 by the authors; licensee Growing Science, Canada doi: $10.5267 /$ j.msl.2021.8.003
} 
includes many forms such as salaries, wages and material rewards, which are written in the contract signed between the parties (Mphil, et al., 2014; Ullah, et al., 2021). This means that the increased performance of the talents relates to their access to appropriate (FC), which is formally agreed upon and documented. Dessler (2011) defines FC as all forms of financial payments for work performed by human resources. In the sense of all the money that goes to the talents under any label was a FC for his work. From another point of view, (FC) is the process of paying and rewarding human resources in return for contributions to the Organization (Stewart \& Brown, 2009). Thus, the talents that contribute to their time, effort, ability, and ability to achieve the Organization's goals must be financially compensated. Accordingly, FC can be defined as a function whereby talents are compensated with directly agreed salaries and wages because of their contribution to their skills and talents to accomplish the various works and tasks entrusted to them and responsible for them. There are many FC systems and to determine which ones are the best. Several factors must be considered, such as the organization's strategy, the culture of society, the competitive environment, the characteristics of human resources, and the organization's ownership of a conceptual and theoretical framework (FC) (Gerhat, et al., 1995). Therefore, it is a good idea to design a system of compensating talents that is consistent with the above factors and helps them achieve their goals.

\subsection{Career Planning}

Career Planning (CP) is the first step in charting the right career path to talents and reaching their ambitions, where talents are the primary focus of planning. Planning provides an opportunity for all to participating in talent development because they collect data on all aspects of career talents life. CP is defined as an individual-level activity for human resources (Kayalar \& Ozmutaf, 2009), or share responsibility with the organization, where human resources determine their ambitions and capabilities and assess their development needs, while the organization identifies its needs and opportunities and ensures that human resources have access to appropriate information (Antoniu, 2010). In addition, (CP) is a continuous discovery process for development (Kumari, 2015). When human resources have developed psychological, behavioral and educational characteristics, they make tremendous progress in career planning (Mikacic, 2015). (CP) includes four key elements: self-assessment, fact checking, goal setting, and planning (Waddell \& Bauer, 2005). We can define (CP) as an activity that analyzes logical the tasks that a human resource can perform, as well as identifying future career paths based on its own development efforts that must be consistent with the organization's needs to survive and continue its work.

\subsection{Talent Retention}

Talent Retention (TR) strategy is identified as the critical and indispensable condition for the long-term survival of organizations in strong and continuously growing markets because they reduce the costs they incur from the increased turnover of talents. The retention of talent is the latest conflict faced by organizations in their quest for talent (Iyria, et al., 2014). TR is an ongoing process designed to keep the talent in the organization and with their full desire without pressure on them (Isfahani \& Boustani, 2014; Osaro, 2016; Hejase, et al., 2016). Retention is a constant commitment and exchange of talents for business with an organization that is making efforts to create an enhanced environment for their survival described through policies and practices that meet their diverse needs (Das \& Baruah, 2013). The importance of TR with the savings of this strategy is linked to the reduction of costs resulting from attracting and developing new talents due to the increased turnover of talents (Sinha \& Sinha, 2012). The retention strategy must adapt to the importance of talent to the organization and be linked to the factors that encourage talent retention (Veloso, et al., 2014). It is understood that the key importance of TR strategy is to help organizations reduce the costs of pursuing other strategies because high-performance talent learns quickly and helps them be proactive and receptive to new developments that increase customer satisfaction and loss because competitors provide opportunities that stimulate them and cause a negative impact on the organization. When the factors that drive the talents to remain in the organization are identified and provided, they must have specific and good plans that give priority to the talents they wish to maintain and by proposing appropriate work for them (Oladapo, 2014). Therefore, plans should be developed covering the strategy of maintaining high-caliber talents and should be considered in the development of the Organization's policies and strategy.

\subsection{Career Planning}

Career Planning (CP) is the first step in charting the right career path to talents and reaching their ambitions, where talents are the primary focus of planning. Planning provides an opportunity for all to participate in talent development because they collect data on all aspects of career talents life. CP is defined as an individual-level activity for human resources (Kayalar \& Ozmutaf, 2009), or share responsibility with the organization, where human resources determine their ambitions and capabilities and assess their development needs, while the organization identifies its needs and opportunities and ensures that human resources have access to appropriate information (Antoniu, 2010). In addition, CP is a continuous discovery process for development (Kumari, 2015). When human resources have developed psychological, behavioral and educational characteristics, they make tremendous progress in career planning (Mikacic, 2015). CP includes four key elements: self-assessment, fact checking, goal setting, and planning (Waddell \& Bauer, 2005). We can define CP as an activity that analyzes logical the tasks that a human resource can perform, as well as identifying future career paths based on its own development efforts that must be consistent with the organization's needs to survive and continue its work. 


\subsection{Talent Retention}

Talent Retention (TR) strategy is identified as the critical and indispensable condition for the long-term survival of organizations in strong and continuously growing markets because they reduce the costs they incur from the increased turnover of talents. The retention of talent is the latest conflict faced by organizations in their quest for talent (Iyria, et al., 2014). TR is an ongoing process designed to keep the talent in the organization and with their full desire without pressure on them (Isfahani \& Boustani, 2014; Osaro, 2016; Hejase, et al., 2016). Retention is a constant commitment and exchange of talents for business with an organization that is making efforts to create an enhanced environment for their survival described through policies and practices that meet their diverse needs (Das \& Baruah, 2013). The importance of TR with the savings of this strategy is linked to the reduction of costs resulting from attracting and developing new talents due to the increased turnover of talents (Sinha \& Sinha, 2012). The retention strategy must adapt to the importance of talent to the organization and be linked to the factors that encourage talent retention (Veloso, et al., 2014). It is understood that the key importance of TR strategy is to help organizations reduce the costs of pursuing other strategies because high-performance talent learns quickly and helps them be proactive and receptive to new developments that increase customer satisfaction and loss because competitors provide opportunities that stimulate them and cause a negative impact on the organization. When the factors that drive the talents to remain in the organization are identified and provided, they must have specific and good plans that give priority to the talents they wish to maintain and by proposing appropriate work for them (Oladapo, 2014). Therefore, plans should be developed covering the strategy of maintaining high-caliber talents and should be taken into account in the development of the Organization's policies and strategy.

\section{Methodology}

\subsection{Research Problem}

Contemporary organizations bear many responsibilities, especially about how to deal with talents because they are considered a valuable resource that enables organizations to face the challenges and problems generated by rapid environmental changes (Al-Margahi \& Al-Mahmoud, 2018a,b), and TR in the health sector is significant because talents work on the front lines and face risks of disease, fatigue and stress at work (Payne, 2015). Lack of health organizations having a TR strategy impedes achieving their goals (Knight, 2018), although (FC) is awarded in some countries, and a gap in TR remains is a challenge for health organizations (Weshya, 2018; Ingram \& Gold, 2016). The presence of large numbers of patients in health organizations and waiting for them for long periods until they receive treatment due to the lack of talent, so the results of this research can help decision-makers in health organizations operating in Iraqi Kurdistan region in general and the (DKDTC) to make decisions based on scientific evidence to TR in epidemic periods.

\subsection{Research Objectives}

All organizations face a great challenge in TR (Mujtaba \& Jamal, 2018), therefore the current research seeks to achieve the following objectives:

- Testing the relationship between (FC), (CP), and (TR).

- Determine the role and type of mediation role that CP plays in the FC relationship with TR.

\subsection{Research Model}

Fig. 1 demonstrates the nature of the direct and indirect effect between the research variables.

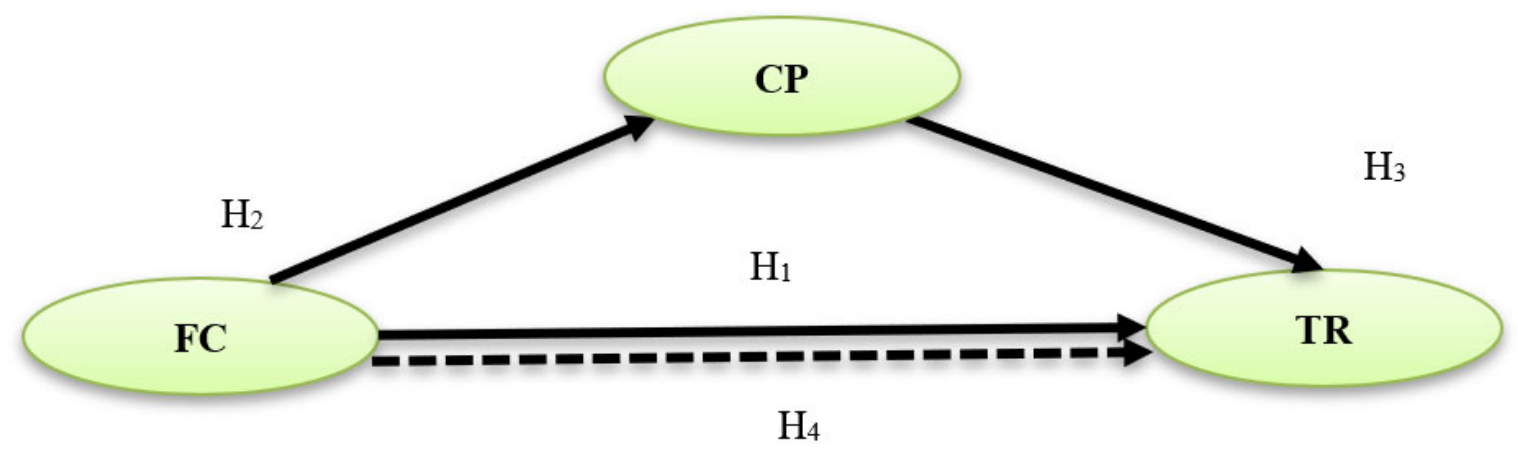

Fig. 1. Research Model 


\subsection{Research Hypotheses}

Four main hypotheses have been formulated to achieve the research objectives, as follows:

- There is a correlation and direct effect statistically significant at a level (0.05) for FC in TR.

- There is a correlation and effect statistically significant at a level (0.05) for FC in CP.

- There is a correlation and effect statistically significant at a level (0.05) for CP in TR.

- There is a correlation and indirect effect statistically significant at a level $(0.05)$ for FC in TR, though CP.

\subsection{Research Reliability}

Appendix 1 clarifies the questionnaire form, and the research used (Guttman Split-Half Coefficient) to obtain accuracy in the research sample answers, in addition to considering it one of the most used methods for calculating the reliability coefficient (Al-Margahi \& Al Mahmoud, 2018). Where indicate all results in table (1) the reliability of the questionnaire scale because they are positive values and surpass the reliability parameter value specified for humanities studies $(0.60)$ (Odeesh \& Salih, 2020).

Table 1

Research Reliability

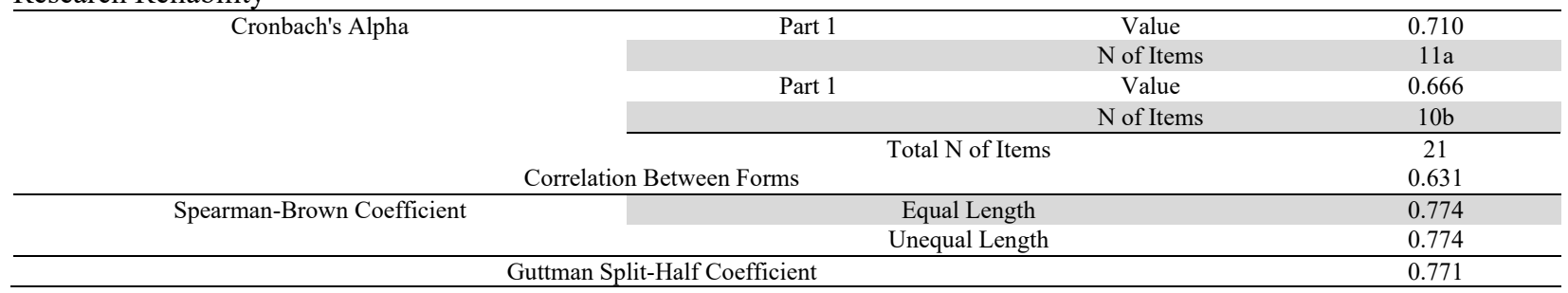

a. (FC1, FC3, FC5, FC7, CP9, CP11, CP13, TR15, TR17, TR19, TR21).

b. (FC2, FC4, FC6, FC8, CP10, CP12, CP14, TR16, TR18, TR20).

\subsection{Research Sample Description}

The results in Fig. 2 explain the characteristics of the study sample.

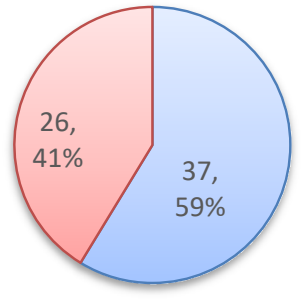

$\square$ Male $\square$ Female

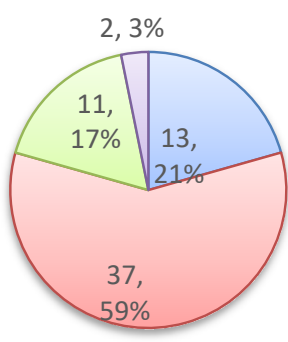

$\square 30 \quad \square 30--40 \quad \square 40--50 \quad \square>50$

$\square$ Doctor $\square$ Doctor Ass. $\square$ Nurse $\quad \square$ Pharmacist
Age

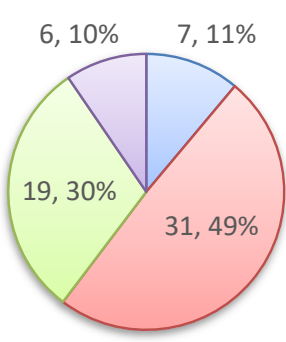

Gender

Job title
$6,8 \%$

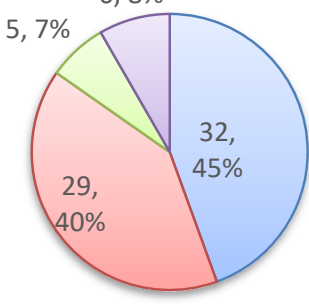

$\square$ Diploma $\square$ BSc $\square \mathrm{MSc} \square \mathrm{PhD}$

Educational background

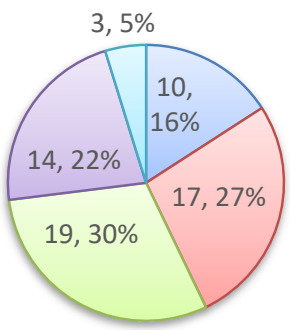

$\square<5 \quad \square 5--10 \quad \square 11--15 \quad \square 16--20 \quad \square>20$

Work Experience (years)

Fig. 2. Personal characteristics of the participants 


\section{Testing and discission hypotheses}

The research relies on (IBM SPSS Amoss V.22) to path analysis between variable, and the result are shown Table 2.

Table 2

Path analysis result

\begin{tabular}{ccccc}
\hline Hypotheses & Path analysis between variable & Estimate & P value & Decision \\
\hline $\mathrm{H}_{1}$ & $\mathrm{FC} \rightarrow \mathrm{TR}$ & 0.919 & 0.000 \\
$\mathrm{H}_{2}$ & $\mathrm{FC} \rightarrow \mathrm{CR}$ & 0.676 & 0.000 \\
$\mathrm{H}_{3}$ & $\mathrm{CP} \rightarrow \mathrm{TR}$ & 0.475 & $\mathrm{Accept}$ & 0.000 \\
$\mathrm{H} \mathrm{H}_{4}$ & $\mathrm{FC}--\rightarrow \mathrm{CR}--\rightarrow \mathrm{TR}$ & 0.598 & 0.000 \\
\hline $\mathrm{P}<0.05$ & & & Accept & Accept \\
\hline
\end{tabular}

$\mathrm{H}_{1}$ : We accept the first Hypothesis, because the level of significance (0.000) is less than the level of significance specified in the research (0.05). Depending on the value of (Estimate), the (FC) affects (TR) in (DKDTC), and this indicates that a change in one unit of (FC) leads to change at a rate (0.919) in (TR).

$\mathrm{H}_{2}$ : The results show the existence of a positive significant relationship between (FC) and (CR) in (DKDTC), relies on the level of significance $(0.000)$ is less than the level of significance specified in the research (0.05). Accordingly, the second hypothesis was accepted. The value of $(\beta)$ read that any change of one unit of $(\mathrm{FC})$ leads to a change in percentage $(0.676)$ in (CR).

$\mathrm{H}_{3}$ : A positive significant relationship was observed between (CR) and (TR) in (DKDTC), because the level of significance of research (0.05) is more than shown by the results of the analysis $(0.000)$. This is consistent with the results of a study (Al Aina \& Atan, 2020: 13). Thus, the (CR) effect on (TR), and if there were an initiative to change (CR) at the rate of one unit that's driven to change (TR) at rate $(0.475)$. And based on that we accept the third hypothesis.

$\mathrm{H}_{4}$ : The main hypothesis was accepted, and that depends on the level of significance $(0.000)$ is less than the level of significance specified in the research (0.05). This means that (FC) effect on (TR) through (CR) at a rate (0.598), and (CR) has a partial mediating role in the relation between (FC) and (TR) in (DKDTC), for the value of (Estimate) in direct path is more than indirect path.

\section{Conclusion and recommendation}

Path analysis results show the existence of a relationship between the research variables, and CP has a partial mediating role in the relationship of FC with TR. Therefore, to increase the ability of DKDTC to TR in (COVID-19) and pandemic age should increase their attention to FC and CP, and that by attention of the following steps:

1- Sharing DKDTC with talents any information about modifying or changing FC and the appropriate career paths that they can take in the future, and here researchers suggest using open book management (Altaii, et al., 2020).

2- Increasing (DKDTC)'s ability to TR requires that FC be linked with the living needs of the talents and be proportionate to their requirements.

3- Talents loyalty towards achieving (DKDTC)'s goals, meeting the societal needs, facing challenges, and performing new, innovative and difficult tasks in time of (COVID-19) epidemic, should calculate (FC) as basic to help health organizations (TR), so that is equivalent with the qualifications, skills, and experiences required by the responsibilities and duties of their jobs, and talents receive remunerative bonuses in addition to their salary.

4- (DKDTC) do linking (CP) with talent development tasks, in addition to motivating talents to consider their goals and the strategic plans of (DKDTC) when planning possible future career paths.

5- Facing (COVID-19) epidemic, (DKDTC) need to (TR) and consider talents as their sustainable competitive advantages, identify areas of investment in them, and take participation, responsibility in (CP), which helps them familiarize them with their strengths and weaknesses and what are the requirements for future jobs.

6- To enhance the ability of (DKDTC) and health organizations to (TR), they must be relying financial compensation, and (CP) programs that include steps (Jain \& Jain, 2011) that achieves harmony between who have talents and capabilities, and the organizations obtain them in a timely manner that meets their needs and exploits available opportunities facing (COVID-19) epidemic.

\section{References}

Al Aina, R., \& Atan, T. (2020). The Impact of Implementing Talent Management Practices on Sustainable Organizational Performance. Sustainability, 12(20), 8372.

Al-Margahi, J.Y.O. \& Al- Mahmoud, S.F.A., (2018), Human resources development as entrance in talent management. Humanities Journal of University of Zakho (HJUOZ), 6(3), 850-869. 
Al-Margahi, J.Y.O. \& Al- Mahmoud, S.F.A., (2018). The European Model of Organizational Excellence as a Tool for Retaining Talent. Humanities Journal of University of Zakho (HJUOZ), 6(4), 1118-1136.

Altaii, M.A.H., Ismail, H.K., \& Khudhur, S.A. (2020). The role of Open-book Management in Achieving Organizational Agility. Academic Journal of Nawroz University (AJNU), 9(1), 232-244.

Antoniu, E., (2010), Career Planning Process and its Role in Human Resource Development. Annals of the University of Petrosani-Economics, 10(2), 13-22.

Bani-Hani, J.S. (2021). The moderating influence of managers strategic thinking on the effect of talent management on organization core competency. Management Science Letters, 11(1), 213-222.

Collings, D. G., McMackin, J., Nyberg, A. J., \& Wright, P. M. (2021). Strategic human resource management and COVID-19: Emerging challenges and research opportunities. Journal of Management Studies.

Collings, D.G., McMackin, J., Nyberg, A.J., \& Wright, P.M. (2021). Leading Through Leading through Paradox in a COVID19 World: Human Resources Comes of Age. Human Resources Management Journal, 1-15.

Das, B.L. \& Baruah, M. (2013), Employee Retention: A Review of Literature. IOSR Journal of Business and Management, 14(2), 8-16.

Dessler, G. (2011). Human Resource Management, 12 ${ }^{\text {th }}$ Edition, Pearson Education Limited Publication Co., Harlow, England.

Gerhat, B., Minkoff, H., \& Oslen, R. (1995). Employee Compensation: Theory, Practice, and Evidence. Center for Advanced Human Resource Stydies. Comell University, New York, USA.

Hejase, H.J., EL Dirani, A, Hamdar, B., \& Hazimeh, B. (2016). Employee Retention in the Pharmaceutical Companies: Case of Lebanon. IOSR Journal of Business and Management, 18(4), 58-75.

Ingram, T., \& Glog, W. (2015). Talent Management in Healthcare Organizations- Qualitative Research Results, 3rd Global Conference on Business, Economics, Management and Tourism, 26-28 November 2015, Rome, Italy.

Iyria, R.K., Namusonge, G.S., \& Karanja, K. (2014). Effect of Talent Retention on Organization Performance in Companies Listed in Nairobi Securities exchange in Kenya. European Journal of Business and Social Sciences, 3(1), 47-58.

Isfahani, A.C.\& Boustani, H.R. (2014). Effects of Talent Management on Employees Retention: The Mediate Effect of Organizational Trust. International Journal of Academic Research in Economics and Management Sciences, 3(5), 114-128.

Ivancevich, J.M. (2010). Human Resource Management. $11^{\text {th }}$ Edition, McGraw-Hill Publishing Co., New York, USA.

Kayalar, M. \& Ozmutaf, M. (2009). The Effect of Individual Career Planning on Job Satisfaction: A Comparative Study on Academic and Administrative Staff. The Journal of Faculty of Economics and Administrative Sciences, 14(1), $239-254$.

Knight, F.L. (2018). Strategies to Retain Employees in the Health Care Industry, Dissertation for Ph.D., College of Management and Technology, Walden University, Minneapolis, USA.

Kumari, R., (2015). Career Planning and its Role in Human Resource Development. International Journal in Commerce, IT \& Social Sciences, 2(3), 119-131.

Mikacic, M.T., (2015), The Effects of Career Planning Education. Revija Za Univerzalno Odlicnost, 4(3), 92-109.

Moczydlowska, J. (2012). Talent Management: Theory and Practice of Management; The Polish Experience. International Journal in Business Management and Economics Researches, 3(1), 432-438.

Mphil, A.H., Ramzan, M., Zubair, H.M.K., Ali, G. \& Arslan, M. (2014). Impact of Compensation on Employee Performance (Empirical Evidence from Banking Sector of Pakistan). International Journal of Business and Social Science, 5(2), 302309.

Mujtaba, M. \& Jamal, S. (2018), Enhancing Work Climate to Improve the Perceived Performance Leading to Talent Retention-A Study of Pakistani Service Sector. International Journal of Social Sciences Perspectives, 5(1), 21-35.

Odeesh, J.Y. \& Salih, S.F. (2020). The Role of Green Human Resource Management Functions in Promoting Blue Ocean Strategy. Humanities Journal of University of Zakho (HJUOZ), 8(1), 129-145.

Oladapo, V. (2014). The Impact of Talent Management on Retention. Journal of Business Studies Quarterly, 5(3), 19-36.

Osaro, C. (2016), Talent Attraction and Employee Retention in Oil Firms in Rivers State. International Journal of Novel Research in Humanity and Social Sciences, 3(2), 75-84.

Payne, (2015), Literature Review: Recruitment and Retention in Health and Human Services, Southern Area Consortium of Human Services: A Program of the Academy for Professional Excellence at San Diego State University School of Social Work.

Sinha, C., \& Sinha, R. (2012). Factors Affecting Employee Retention: A Comparative Analysis of two Organizations from Heavy Engineering Industry. European Journal of Business and Management, 4(3), 145-163.

Stewart, G.L., \& Brown, K.G. (2009). Human Resource Management: Linking Strategy to Practice. John Wiley \& Sons. Inc., New Jersey, USA.

Ullah, M.R., Kamran, H.W., Akram, S., Nawaz, M.A., \& Rwhman, F. (2021). Organizational antecedents and talent turnover: A relational analysis of credit card departments of bank. Management Science Letters, 11(4), 1211-1220.

Veloso, E.F.R., Silva, R.C.D., Dutra, J.S., Fischer, A.L., \& Trevisan, L.N. (2014). Talent Retention Strategies in Different Organizational Contexts and Intention of Talents to Remain in the Company. RISUS - Journal on Innovation and Sustainability, 5(1), 49-61.

Waddell, J. \& Bauer, M., (2005), Career Planning and Development for Students: Building a Career in a Professional Practice Discipline. Canadian Journal of Career Development, 4(2), 4-13. 
Weshya, F.N. (2018). Factors Influencing Retention of Professional Nurses in a Public Health Care Facility in WindhoekNamibia, Thesis for MSc. In Nursing Science, Faculty of Medicine and Health Sciences, Stellenbosch University, Stellenbosch, South Africa.

\section{Appendix 1}

Questionnaire

First: Financial Compensation (FC):

\begin{tabular}{|c|c|c|c|c|c|c|}
\hline No. & +2 & $\begin{array}{l}\text { Strongly } \\
\text { Agree (5) }\end{array}$ & $\begin{array}{l}\text { Agree } \\
\text { (4) }\end{array}$ & $\begin{array}{c}\text { Neutral } \\
\text { (3) }\end{array}$ & $\begin{array}{l}\text { Disagree } \\
(2)\end{array}$ & $\begin{array}{c}\text { Strongly } \\
\text { Disagree (1) }\end{array}$ \\
\hline FC1 & $\begin{array}{l}\text { Financial compensation is commensurate with the working condi- } \\
\text { tions, challenges and problems facing my jobs in (DKDTC). }\end{array}$ & & & & & \\
\hline FC2 & $\begin{array}{l}\text { Financial compensation is equivalent to the qualifications, skills and } \\
\text { experience that the responsibilities and duties of jobs in (DKDTC) } \\
\text { require. }\end{array}$ & & & & & \\
\hline FC3 & $\begin{array}{l}\text { Job analysis and description are depending as a basis for determining } \\
\text { financial compensation, and according to clear, logical and easy-to- } \\
\text { understand principles. }\end{array}$ & & & & & \\
\hline FC4 & $\begin{array}{l}\text { Financial compensation system used is characterized by fairness and } \\
\text { equality, and the increases (bonuses and promotions) are commensu- } \\
\text { rate with the nature of the jobs in (DKDTC). }\end{array}$ & & & & & \\
\hline FC5 & $\begin{array}{l}\text { Financial compensation is linked to the human resources ability in } \\
\text { (DKDTC) to achieve the set goals. }\end{array}$ & & & & & \\
\hline FC6 & $\begin{array}{l}\text { Financial compensation is commensurate with the requirements and } \\
\text { living needs of the human resources operating in (DKDTC). }\end{array}$ & & & & & \\
\hline FC7 & $\begin{array}{l}\text { Human resources in (DKDTC) get feedback on any modification or } \\
\text { change in the financial compensation. }\end{array}$ & & & & & \\
\hline FC8 & $\begin{array}{l}\text { Financial compensation varies between different jobs in their respon- } \\
\text { sibilities and duties. }\end{array}$ & & & & & \\
\hline \multicolumn{7}{|c|}{ Second: Career Planning (CR): } \\
\hline CR9 & (DKDTC) adopts logical and scientific career planning methods. & & & & & \\
\hline CR10 & $\begin{array}{l}\text { Human resources in (DKDTC) share in choosing the career paths that } \\
\text { they can pursue it in their career. }\end{array}$ & & & & & \\
\hline CR11 & $\begin{array}{l}\text { (DKDTC) adopts career planning policies that assist in directing and } \\
\text { support human resources with the necessary information on career } \\
\text { paths. }\end{array}$ & & & & & \\
\hline CR12 & $\begin{array}{l}\text { Human resource considers its goals and (DKDTC)'s strategic plans } \\
\text { when planning future career paths. }\end{array}$ & & & & & \\
\hline CR13 & $\begin{array}{l}\text { (DKDTC) works to achieve the connect between career planning } \\
\text { functions and human resource development. }\end{array}$ & & & & & \\
\hline CR14 & $\begin{array}{l}\text { Career planning contributes to identifying opportunities and areas of } \\
\text { investment in human resources. }\end{array}$ & & & & & \\
\hline \multicolumn{7}{|c|}{ Third: Talent Retention (TR): } \\
\hline TR15 & $\begin{array}{l}\text { (DKDTC) provides creative opportunities for talented human re- } \\
\text { sources and provides them with the required supplies. }\end{array}$ & & & & & \\
\hline TR16 & $\begin{array}{l}\text { (DKDTC) provides all forms of support to the talented human re- } \\
\text { sources in order to retention them. }\end{array}$ & & & & & \\
\hline TR17 & $\begin{array}{l}\text { Talented human resources participate in achieving (DKDTC)'s goals, } \\
\text { meeting the needs of the community, facing challenges, and perform- } \\
\text { ing new, innovative and difficult tasks. }\end{array}$ & & & & & \\
\hline TR18 & $\begin{array}{l}\text { (DKDTC) works to be talented human resources its first sustainable } \\
\text { competitive advantage. }\end{array}$ & & & & & \\
\hline TR19 & $\begin{array}{l}\text { (DKDTC) identifies the strengths of talented human resources, and } \\
\text { what are the requirements needed for future jobs. }\end{array}$ & & & & & \\
\hline TR20 & $\begin{array}{l}\text { (DKDTC) works to ensure that talented human resources receive re- } \\
\text { warding incentives in addition to their salary and suit their talents. }\end{array}$ & & & & & \\
\hline TR21 & $\begin{array}{l}\text { (DKDTC) seeks to obtain a good reputation for retaining talented hu- } \\
\text { man resources by ensuring that appropriate leadership style is fol- } \\
\text { lowed in its dealings with them. }\end{array}$ & & & & & \\
\hline
\end{tabular}


(C) 2022 by the authors; licensee Growing Science, Canada. This is an open access article distributed under the terms and conditions of the Creative Commons Attribution (CC-BY) license (http://creativecommons.org/licenses/by/4.0/). 